\title{
Assessment of Land Suitability for Agriculture in the Southeastern Sector of Siwa Oasis
}

\author{
Ramzy M. R. Hedia ${ }^{1}$, Osama R. Abd Elkawy ${ }^{1}$
}

\begin{abstract}
In the light of continued population growth and increased congestion in the old Nile Valley and Delta, the need for land reclamation of the desert areas in Egypt appears inevitable. This study attempted to investigate the best agricultural land use for a new land area in the Southeastern sector of Siwa oasis based on its soil characteristics and irrigation water quality. The fieldwork was carried out during the year 2013 where soil and groundwater samples were collected for different analyses. The agricultural land use suitability was assessed using ALESarid-GIS. The main soil characteristics showed high variability where soil salinity, soil alkalinity (ESP, \%), total carbonate content, and soil depth ranged from 0.52 to $208 \mathrm{dS} \mathrm{m}^{-1}$, from 8.04 to $91.54 \%$, from 14.33 to $70.1 \%$, and from 20 to $200 \mathrm{~cm}$, respectively. The study area was represented by seven soil mapping units according to soil depth, salinity and sodicity criteria. Groundwater analysis showed high salinity hazards with low sodium hazards (C3S1). Results of ALESarid-GIS analysis showed that most of the studied area is highly to moderately suitable (S1 to S2) for alfalfa, wheat, barley, sugar beet, and onion, while most of the area is marginally to conditionally suitable (S3 to S4) for pear, date palm, sunflower, cotton, fig, olive, sorghum, and grape in the order indicated. The dominant limiting parameters affecting land suitability for different crops are coarse soil texture, soil salinity, soil permeability, and exchangeable sodium percent. The outcomes of this research represent a valuable resource for governmental agencies concerned about land reclamation projects along with sustainable agricultural development in Siwa oasis.
\end{abstract}

Key words: Land reclamation, Land suitability, ALESarid-GIS, Siwa oasis.

\section{INTRODUCTION}

Only approximately $4 \%$ of Egypt's total area is agricultural land and the majority of the population is concentrated in this area. The remaining $96 \%$ of the land area is an arid desert. This unbalanced distribution of inhabitants causes serious social and economic problems. The ever-increasing population has resulted in a decrease in agricultural area per capita from 0.13 ha in 1947 to 0.05 ha in 2004. In the same context, agriculture is a key sector of the Egyptian economy and the foundation of the rural economy. Agriculture still provides a livelihood for $55 \%$ of the population that has been estimated at about 91 million in 2016 and employs directly $34 \%$ of the labor force. Seen from this perspective, the need for reclamation of the desert appears inevitable in light of continued population growth and increased congestion in the old agricultural lands in the Nile valley and the delta (CAPMS, 2016; Abd Elkawy et al., 2011; Adriansen, 2009; FAO, 2005; IFAD, 2005).

Land reclamation and greening the desert, through applying an agricultural expansion program across the desert areas and near the fringes of the Nile delta, remain high on the agenda of the Egyptian government. It is supported directly or indirectly by international agencies (Adriansen, 2009; Bush, 2007). Since the mid1980s, Egypt has embarked on an ambitious scheme to increase domestic food production through desert reclamation. Since the inception of this program, about 2 million Feddan (one Feddan $=0.42$ hectare) of desert land has been reclaimed by both public and private sector companies (MALR, 2001). The government has a target of 1.5 million Feddan to be reclaimed by 2020, of which thirty thousand Feddan should be in Siwa oasis at the northward of Egypt's western desert. This project aims to create an integrated society inside the new lands and achieve a comprehensive agro-industrial development. Moreover, the project aims to narrow the gap between supply and demand of the foodstuffs and reduce imports and contributes to increasing the populated area in Egypt, in addition to increasing the agricultural farmlands from 8 million feddan to 9.5 million feddan, by an increase of $20 \%$ (SIS, 2016).

Successful desert reclamation requires three key elements: good quality topsoil, adequate water, and reliable electricity supply (MALR, 2001). The present study focuses on the first two elements, soil, and water, through deciding the best agricultural land use based on soil quality and water irrigation quality.

Part of the solution to agricultural land use problems is land evaluation in support of rational land use planning and appropriate and sustainable use of natural resources (Rossiter, 1996). Land evaluation is concerned with the assessment of land performance when used for specified purposes (FAO, 1976). The potential of land for agricultural use is determined by an evaluation of the factors affecting the agricultural land productivity and suitability, such as climate conditions, soil 
characteristics, and water irrigation quality. This evaluation is an essential step for the development of agriculture. Additionally, the identification and accurate description of current and potential production areas are essential for agricultural development, given the important effect of these factors on the transfer of agrotechnological innovations (Corbett, 1996). From this perspective and based on a large amount of data and a large number of criteria used in determining agricultural land use suitability, the assessment of land suitability is recognized as a multi-criteria evaluation (MCE) (Lee, 2003). Although several land evaluation models have been developed to provide a quantified procedure to match land with various actual and proposed uses, there is no single or unified land evaluation modeling approach (Rossiter, 1996 and 2003).

Geographic information systems (GIS) have the ability to perform numerous tasks utilizing both spatial and attribute data. GIS are very useful for storing, processing and manipulating spatial data and their related thematic attributes (Aronoff, 1989). However, GIS has several limitations in the domain of spatial decision-aid (Malczewski, 2004). One approach that can help overcome such limitations is the MCE (Carver, 1991), which has received renewed attention within the context of GIS-based decision-making (Pereira and Duckstein, 1993). The objective of using MCE procedures is to find solutions to decision-making problems characterized by multiple alternatives, which can be evaluated by means of decision criteria (Jankowski et al., 2001). Consequently, the integration of MCE within a GIS context could help users and researchers to improve decision-making processes. An example of the MCE models integrated with GIS and used for land evaluation is ALESarid-GIS "Agriculture Land Evaluation System for arid and semi-arid regions". ALESarid-GIS estimates the best agricultural land use suitability through calculating crop suitability classes and indices for 27 crops (field crops, vegetable and forage crops, and fruit trees). The evaluation is based on crop suitability affected by the environmental potential at the site, such as the physical, chemical and fertility characteristics of the soil, irrigation water quality, and climatic conditions. These environmental factors are used to measure the inherent soil-based qualities of land as they relate to the agricultural suitability (Abd Elkawy et al., 2010).

The objectives of this research are to evaluate the main soil characteristics and irrigation water quality and to assess the best agricultural land use for the uncultivated area in the Southeastern sector of Siwa oasis. The produced agricultural land use could provide decision makers with the information needed for improving the quality of land use decisions and guide them as to what crops are mostly suitable for the area, especially in cases where they have insufficient agricultural knowledge about the new area's land characteristics.

\section{MATERIALS AND METHODS}

\section{Study area:}

The investigated area is located in the Southeastern part of Siwa oasis in Egypt (Fig. 1). It lies approximately between latitude $29^{\circ} 5^{\prime} 27^{\prime \prime}$ and $29^{\circ} 11^{\prime}$ $28^{\prime \prime}$ - longitude $25^{\circ} 27^{\prime} 13^{\prime \prime}$ and $25^{\circ} 49^{\prime} 58^{\prime \prime}$.

It was selected for investigation because of its high priority for future agriculture extension and desert reclamation (SIS, 2016). It covers an area of approximately 33,783 Feddan, and it is accessible via several roads in Siwa oasis. It is bounded by the old agricultural land, Siwa city, and lake Zaitoun from North and sand dunes from South (Fig. 1 and 2). The elevations range from $57 \mathrm{~m}$ below sea level to $91 \mathrm{~m}$ above sea level and most of the study area is unleveled land (Fig. 2). Although an irrigation network system has not yet to be established in the study area, several deep wells for irrigation have already been drilled. At present, the study area consists mostly of uncultivated land, although some private agricultural activities have recently started using the groundwater for irrigation. Groundwater is considered as the only source of water in Siwa oasis.

\section{The Fieldwork and Laboratory Analyses:}

The fieldwork was carried out based on both an unsupervised classified Enhanced Thematic Mapper (ETM+) Landsat image acquired on March 2013 (Fig. 3) and ASTER GLOBAL DEM image acquired on October 2013 (Fig. 2). Locations of soil profiles were based on the variations among the spectral classes identified from both the image and the elevations from the digital elevation model (DEM). ETM+ and DEM images were obtained from the United States Geological Survey website (USGS, 2016). Locations of 50 representative soil profiles were identified using GPS and then dug. The investigated soil profiles were described macro-morphologically in the field according to FAO (1990) and then the soil of the study area was classified according to the American system of soil taxonomy (USDA, 2010).

Soil profile depth was assessed and soil samples were collected for further physical, chemical and fertility analyses. Water irrigation samples were collected from various artesian wells for chemical analyses. Soil and water analyses were carried out according to Page et al., (1982) and Richards (1954), 


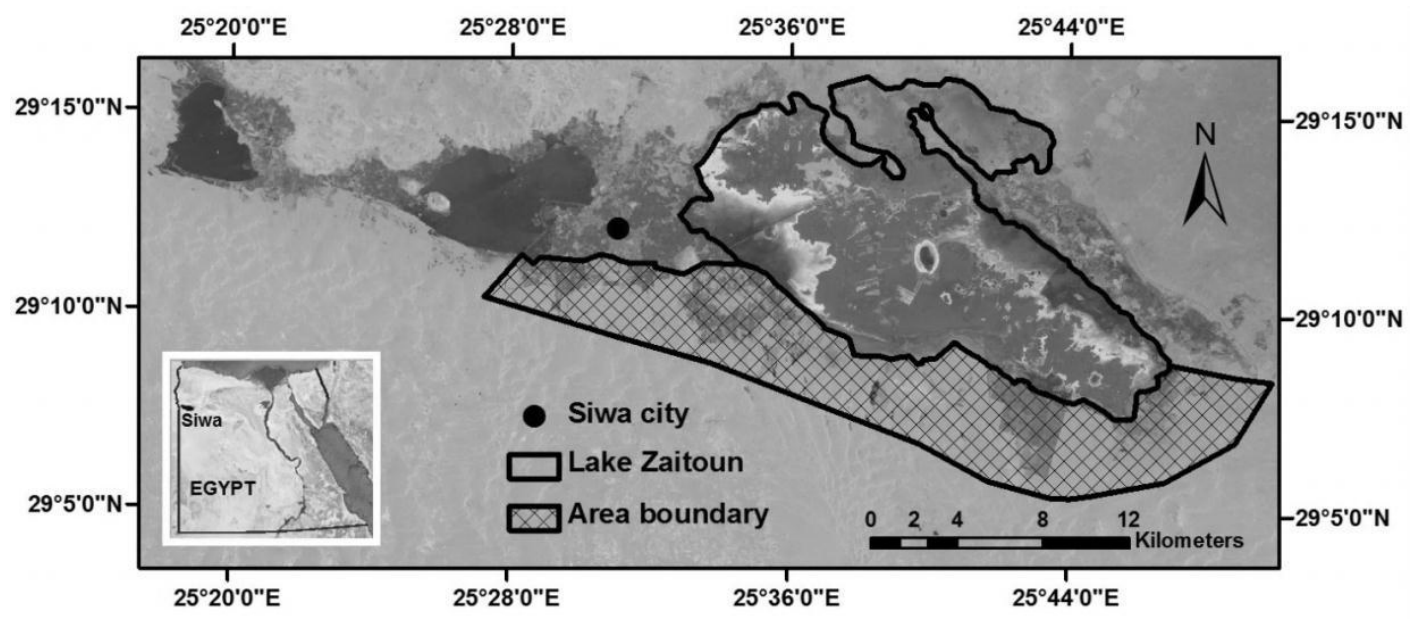

Fig. 1. Location map of the study area on ETM+(2013) Landsat image (USGS, 2016)



Fig. 2. ASTER GLOBAL DEM (2011) of the study area (USGS, 2016)

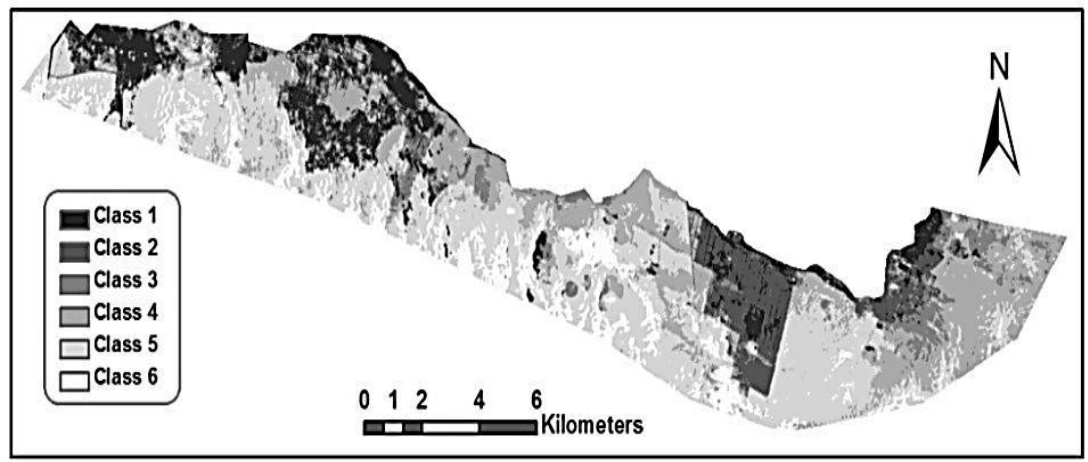

Fig. 3. Unsupervised classified ETM+ Landsat image (2013) of the study area

while soil fertility analyses were carried out according to Jackson (1973), Olsen and Watanabe (1965), and FAO (1970).

\section{Soil survey and soil mapping units:}

Different soil maps (soil salinity, soil alkalinity, soil calcium carbonate content, and soil depth) were constructed through interpolation processes using ArcMap $^{\circledR}$ within ArcGIS $^{\circledR} 10.2$ packages (ESRI, 2015). Only weighted average data of each soil profile were included for map production. A map of soil units was created through overlay operation, in which the abovementioned soil maps were included. 


\section{Assessment of land suitability:}

The land suitability assessment for different crops was achieved using ALESarid-GIS, where land suitability classes were calculated and suitability maps were produced through interpolation processes (Abd Elkawy et al., 2010).

\section{RESULTS AND DISCUSSION}

\section{Soil and water resources characterization:}

The investigated soil is weakly developed and reflects the prevailing dry climatic conditions. The only observed diagnostic horizons are Calcic and Salic horizons and Ochric epipedon. Accordingly, the soil could be classified as soil orders Aridisols and Entisols. Additionally, the Torric moisture regime and the dominant sand soil texture lead to classifying the soil as subgroups Typic Haplocalcids, Typic Haplosalids, and Typic torripsamments.

Main physical and chemical soil properties determine the capability of agricultural production and its suitability for different crops. The descriptive statistics of selected main soil physical and chemical properties of the soil paste extracts of soil samples collected are listed in Table (1). Soil depth ranges from very shallow to deep homogeneous soil $(20-200 \mathrm{~cm})$ with an average of $188.72 \mathrm{~cm}$. Values of the electrical conductivity (EC) range from 0.52 to $208.0 \mathrm{dS} \mathrm{m}^{-1}$ and have a high coefficient of variation $(\mathrm{CV}=169.5 \%)$. The soil $\mathrm{pH}$ measured shows the least variation $(\mathrm{CV}=3.7 \%)$ and ranges from 6.94 to 8.18 representing a neutral to slightly alkaline soil conditions. Exchangeable sodium percentage (ESP) ranges from 8.04 to $91.54 \%$ with moderate variations $(\mathrm{CV}=88 \%)$. Total calcium carbonate ranges from 14.33 to $70.1 \%$ with relatively low variations $(\mathrm{CV}=22.8 \%)$. Although soil organic matter content $(\mathrm{OM})$ and available phosphorus have a very narrow range $(0.0-1.40 \%$ and $0.09-6.0 \mathrm{ppm}$, respectively), they have very high variations among soil samples $(\mathrm{CV}=362$ and $333.3 \%$, respectively). The cation exchange capacity ranges from 5.0 to $10 \mathrm{cmol}^{(+)}$ $\mathrm{kg}^{-1}$ with high variations among soil samples $(\mathrm{CV}=104$ $\%)$. Results of the particle size distribution analysis showed that the soil samples are dominated by sand (79.0 - 87.0\%) and thus have coarse textures.

Table 1. Descriptive statistics of selected soil properties in the Southeastern sector of Siwa oasis

\begin{tabular}{lcccccc}
\hline Parameter & Minimum & Maximum & Range & Average & SD & CV, \% \\
\hline $\mathrm{EC}, \mathrm{dS} \mathrm{m}^{-1^{*}}$ & 0.52 & 208.00 & 207.48 & 18.66 & 31.63 & 169.5 \\
$\mathrm{pH}^{*}$ & 6.94 & 8.18 & 1.24 & 7.62 & 0.28 & 3.7 \\
$\mathrm{ESP}, \%$ & 8.04 & 91.54 & 83.50 & 23.36 & 20.57 & 88.0 \\
$\mathrm{CaCO}_{3}, \%$ & 14.33 & 70.10 & 55.78 & 31.49 & 7.18 & 22.8 \\
$\mathrm{CEC} \mathrm{cmol}_{(+)} \mathrm{kg}^{-1}$ & 5.00 & 10.00 & 5.00 & 6.20 & 6.45 & 104.0 \\
Soil depth, cm & 20.00 & 200.00 & 180.00 & 188.72 & 42.14 & 22.3 \\
clay, \% & 9.00 & 14.00 & 5.00 & 10.20 & 2.98 & 29.2 \\
Silt, \% & 5.00 & 12.00 & 7.00 & 9.30 & 1.44 & 15.5 \\
Sand, \% & 79.00 & 87.00 & 8.00 & 83.00 & 3.49 & 4.2 \\
OM, \% & 0.00 & 1.40 & 1.40 & 0.58 & 2.10 & 362.1 \\
Available N, ppm & 0.00 & 95.00 & 95.00 & 37.20 & 35.10 & 94.4 \\
Available P, ppm & 0.09 & 6.00 & 5.91 & 0.36 & 1.20 & 333.3 \\
\hline
\end{tabular}

Measured in soil paste extracts.

Table 2.Classes and area percent distribution of selected soil properties in the Southeastern sector of Siwa oasis

\begin{tabular}{lclccccc}
\hline \multicolumn{2}{c}{$\mathrm{CaCO}_{\mathbf{3}}$ \% \% } & \multicolumn{2}{c}{ Soil depth, cm } & \multicolumn{2}{c}{ EC, dS m } & \multicolumn{2}{c}{ ESP, \% } \\
\hline \multicolumn{1}{c}{ Class } & Area \% & Class & Area \% & Class & Area \% & Class & Area \% \\
\hline$<20$ & 0.4 & $<50$ & 3.3 & $<2$ & 0.5 & $<15$ & 30.1 \\
$21-40$ & 91.1 & $50-100$ & 2.9 & $2.1-4$ & 2.9 & $16-30$ & 53.0 \\
$41-60$ & 8.2 & $>100$ & 93.8 & $4.1-8$ & 22.3 & $31-45$ & 8.3 \\
$>60$ & 0.4 & & & $8.1-16$ & 37.9 & $46-60$ & 4.5 \\
& & & & $>16$ & 36.4 & $>60$ & 4.1 \\
\hline
\end{tabular}


Table 3. Descriptive statistics of selected properties of different groundwater wells in the Southeastern sector of Siwa oasis

\begin{tabular}{lcccccc}
\hline Parameter & Minimum & Maximum & Range & Average & SD & CV, \% \\
\hline $\mathrm{EC}, \mathrm{dS} \mathrm{m}{ }^{-1}$ & 1.01 & 1.74 & 0.73 & 1.40 & 0.21 & 14.9 \\
$\mathrm{pH}$ & 7.22 & 7.80 & 0.58 & 7.65 & 0.16 & 2.1 \\
Soluble ions, me 1' & & & & & & \\
$\mathrm{Ca}^{2+}$ & 0.60 & 1.20 & 0.60 & 0.92 & 0.22 & 24.2 \\
$\mathrm{Mg}^{2+}$ & 0.40 & 1.80 & 1.40 & 1.06 & 0.47 & 43.9 \\
$\mathrm{Na}^{+}$ & 5.54 & 8.04 & 2.50 & 6.83 & 0.83 & 12.1 \\
$\mathrm{~K}^{+}$ & 0.18 & 0.26 & 0.08 & 0.22 & 0.03 & 13.3 \\
$\mathrm{CO}_{3}^{2-}$ & 0.0 & 0.20 & 0.12 & 1.06 & 0.49 & 46.3 \\
$\mathrm{HCO}_{3}^{-}$ & 3.40 & 6.80 & 3.40 & 5.48 & 1.06 & 19.3 \\
$\mathrm{Cl}^{-}$ & 4.50 & 10.00 & 5.50 & 6.75 & 1.68 & 24.8 \\
$\mathrm{~B}, \mathrm{ppm}$ & 0.10 & 0.60 & 0.50 & 0.40 & 0.16 & 40.2 \\
$\mathrm{SAR}$ & 5.87 & 8.83 & 2.96 & 7.03 & 0.97 & 13.7 \\
\hline
\end{tabular}

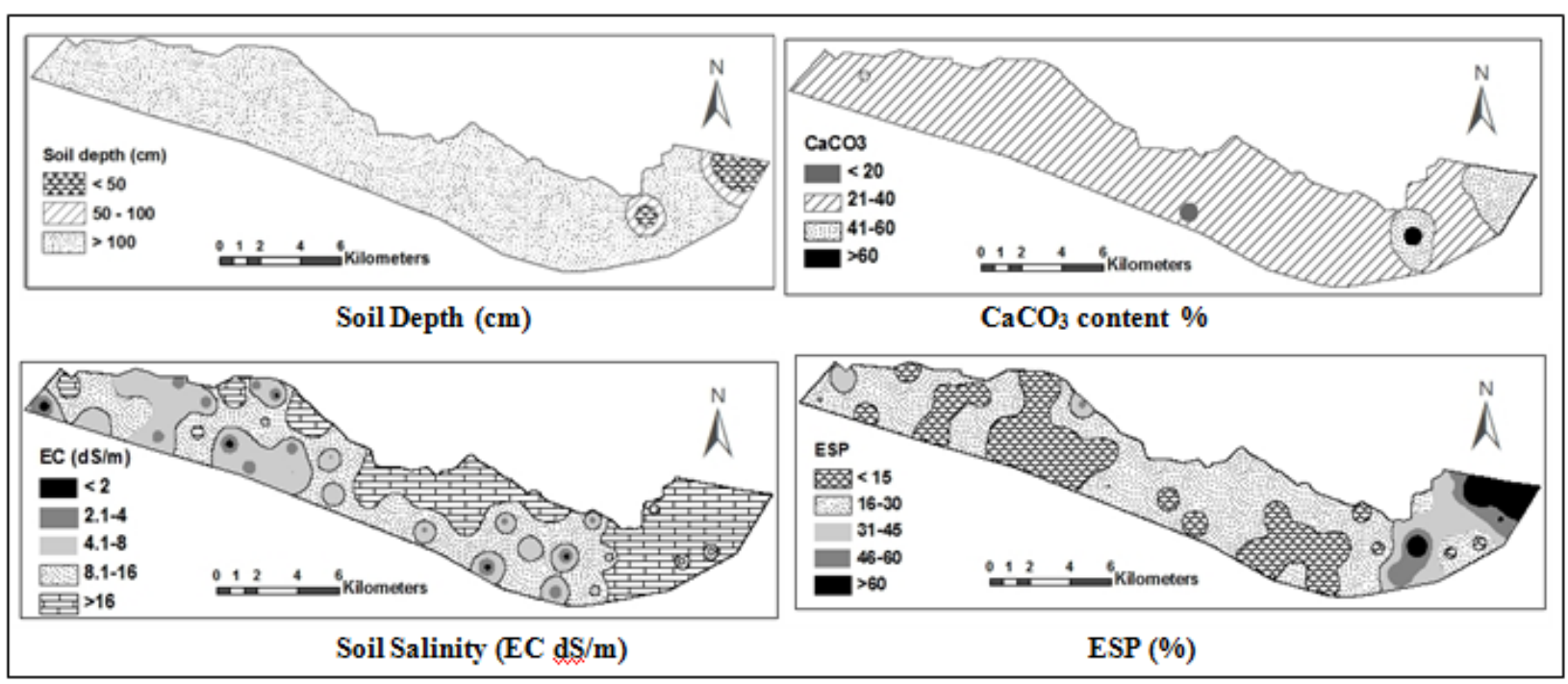

Fig. 4. Spatial distribution of selected soil properties in the Southeastern sector of Siwa oasis

The spatial distribution of soil salinity, soil alkalinity, total calcium carbonate content, and soil depth are summarized and presented in Table (2) and Fig. (4) . More than $93 \%$ of the area has soil depth > $100 \mathrm{~cm}$ and the areas with soil depth $<100 \mathrm{~cm}$ are located in the most Eastern part of the study area (Fig. 4). More than $91 \%$ of the area has $\mathrm{CaCO}_{3}$ contents from 21 to $40 \%$. About $96.6 \%$ of the area has EC values $>4$ $\mathrm{dS} \mathrm{m}^{-1}$ (saline soil conditions). However, areas with EC> 16 are found in the areas with shallow soil depth and/or adjacent to the lake Zaitoun, East and Northeastern parts of the sector (Fig. 4). About $69.9 \%$ of the area has ESP> $16 \%$ (sodic soil conditions). The highest ESP values are also found in the most Eastern part of the studied area (Fig. 4).
Statistics of the results of groundwater analysis (Table 3) shows that the EC of the sampled wells ranges from 1.01 to 1.74 with an average of $1.40 \mathrm{dS} \mathrm{m}^{-1}$ and it has low variations $(\mathrm{CV}=14.9 \%)$. The $\mathrm{pH}$ also has a very narrow range $(7.22-7.80)$ and very low variations $(\mathrm{CV}=2.1 \%)$. $\mathrm{Na}^{+}$ions prevail the major soluble ion followed by the other cations in the order $\mathrm{Mg}^{+2}>\mathrm{Ca}^{2+}>$ $\mathrm{K}^{+}$. The calculated SAR has an average of 7.03. Chloride ions represent the majority of the soluble anions followed by the other major anions in the order $\mathrm{HCO}_{3}{ }^{-}>\mathrm{CO}_{3}{ }^{2-}$. Boron in the sampled wells ranges from 0.1 to $0.6 \mathrm{ppm}$ with an average of $0.4 \mathrm{ppm}$. According to Ayers and Westcot (1985), groundwater of the sampled wells is expected to have slight to moderate restrictions when used in irrigation due to its soluble salts content. 
No infiltration problems are expected from this water when used in irrigation, except the well with SAR> 6 at the measured EC $\left(1.01-1.74 \mathrm{dS} \mathrm{m}^{-1}\right)$. Similarly, this water is also classified as $\mathrm{C} 3 \mathrm{~S} 1$ according to Richards (1954). However, boron concentration in the sampled groundwater seems to have no restriction for irrigation of crops $(<0.7 \mathrm{ppm})$.

\section{Soil mapping units}

The resulted soil mapping units showed that the study area is characterized by one main soil unit which is calcareous $\left(\mathrm{CaCO}_{3}>14 \%\right)$. This soil unit is divided into seven soil subunits which are displayed in Fig. 5. The following is a brief description of these subunits:

- Non-alkaline, none to moderately saline, very deep soil: It occupies $2.5 \%$ of the study area. It has low levels of soil alkalinity and salinity (ESP < 15, EC < $4 \mathrm{dS} / \mathrm{m}$ ) and soil depth is more than $100 \mathrm{~cm}$.

- Non-alkaline, saline to very saline, very deep soil: It occupies $27.8 \%$ of the study area and it is similar to the first subunit but soil salinity ranges from 4 to 16 $\mathrm{dS} / \mathrm{m}$.

- Alkaline, none to moderately saline, very deep soil: It occupies $0.9 \%$ of the study area and it is similar to the first subunit but it has high soil alkalinity value (ESP > 15).

- Alkaline, saline to very saline, very deep soil: It occupies $32.4 \%$ of the study area and it has high soil alkalinity value (ESP > 15). Soil salinity ranges from 4 to $16 \mathrm{dS} / \mathrm{m}$ and soil depth is more than $100 \mathrm{~cm}$.

- Alkaline, extremely saline, very deep soil: It occupies $30.2 \%$ of the study area and it is similar to the previous subunit but it is characterized by very high levels of soil salinity (EC $>16 \mathrm{dS} / \mathrm{m}$ ).
- Alkaline, extremely saline, moderately deep to deep soil: It occupies $3 \%$ of the study area. It has high soil alkalinity value $(\mathrm{ESP}>15)$ and very high levels of soil salinity $(E C>16 \mathrm{dS} / \mathrm{m})$. Soil depth ranges from 50 to $100 \mathrm{~cm}$

- Alkaline, extremely saline, very shallow to shallow soil: It occupies $3.2 \%$ of the study area and it is similar to the previous subunit but soil depth is less than $50 \mathrm{~cm}$.

\section{Assessment of land suitability:}

The assessment of land suitability of the studied area using ALESarid-GIS was carried out to determine the suitability degree of the land for different crops under the current soil and water characteristics. The spatial distribution of land suitability and the percent area of each suitability class for different field crops are presented in Fig. 6 and Table 4, respectively. The study area is classified as S1 (highly suitable) for cultivating alfalfa, wheat, and barley with 47,20 and $15 \%$ of the area, respectively. It was also found that $39,59,72,74$ and $57 \%$ of the area are classified as S2 (moderately suitable) for alfalfa, wheat, barley, sugar beet, and onion, respectively (Table 4). Less area percent values belong to S3 (marginally suitable) and S4 (conditionally suitable) for those crops. For sunflower, cotton, and sorghum 83,83 , and $65 \%$ of the area belong to S3, respectively and the rest of the area is classified as $\mathrm{S} 4$ or NS1 (potentially suitable).

The spatial distribution of land suitability classes for fruit crops and the area percent of each class (Fig. 7 and Table 4) revealed that the whole study area is not classified as S1 for fruit crops (area \%=0). However, the study area seems to be moderately suitable for pear (area $\%=49$ for $\mathrm{S} 2$ class).

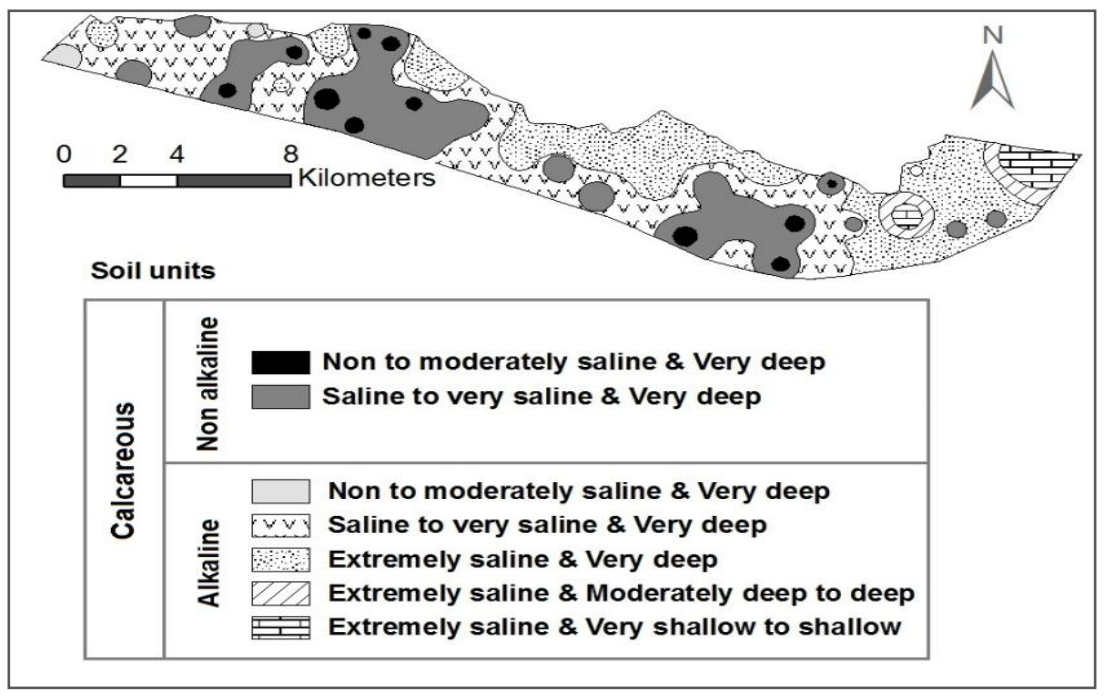

Fig. 5. Soil mapping subunits of the Southeastern sector of Siwa oasis 
Table 4. Land suitability classes and their area percents for different crops in the Southeastern sector of Siwa oasis

\begin{tabular}{|c|c|c|c|c|c|c|}
\hline \multirow{2}{*}{ Crops } & \multicolumn{6}{|c|}{ Land suitability classes* } \\
\hline & S1 & S2 & S3 & S4 & NS1 & NS2 \\
\hline & & $\begin{array}{c}----- \\
--1\end{array}$ & ----- & Area $\%$ & $-\cdots$ & \\
\hline Alfalfa & 47 & 39 & 13 & 1 & 0 & 0 \\
\hline Wheat & 20 & 59 & 18 & 3 & 0 & 0 \\
\hline Barley & 15 & 72 & 8 & 5 & 0 & 0 \\
\hline Sugar beet & 0 & 74 & 20 & 6 & 0 & 0 \\
\hline Onion & 0 & 57 & 37 & 6 & 0 & 0 \\
\hline Sun flower & 0 & 0 & 83 & 16 & 1 & 0 \\
\hline Cotton & 0 & 0 & 83 & 15 & 2 & 0 \\
\hline Sorghum & 0 & 0 & 65 & 34 & 1 & 0 \\
\hline Pear & 0 & 49 & 37 & 9 & 2 & 3 \\
\hline Date Palm & 0 & 1 & 87 & 7 & 2 & 3 \\
\hline Fig & 0 & 0 & 74 & 20 & 2 & 4 \\
\hline Olive & 0 & 0 & 67 & 27 & 2 & 4 \\
\hline Grape & 0 & 0 & 58 & 38 & 2 & 2 \\
\hline Citrus & 0 & 0 & 1 & 3 & 3 & 93 \\
\hline
\end{tabular}

*S1: highly suitable, S2: moderately suitable, S3: marginally suitable,

S4: conditionally suitable, NS1: potentially suitable, NS2: actually unsuitable.

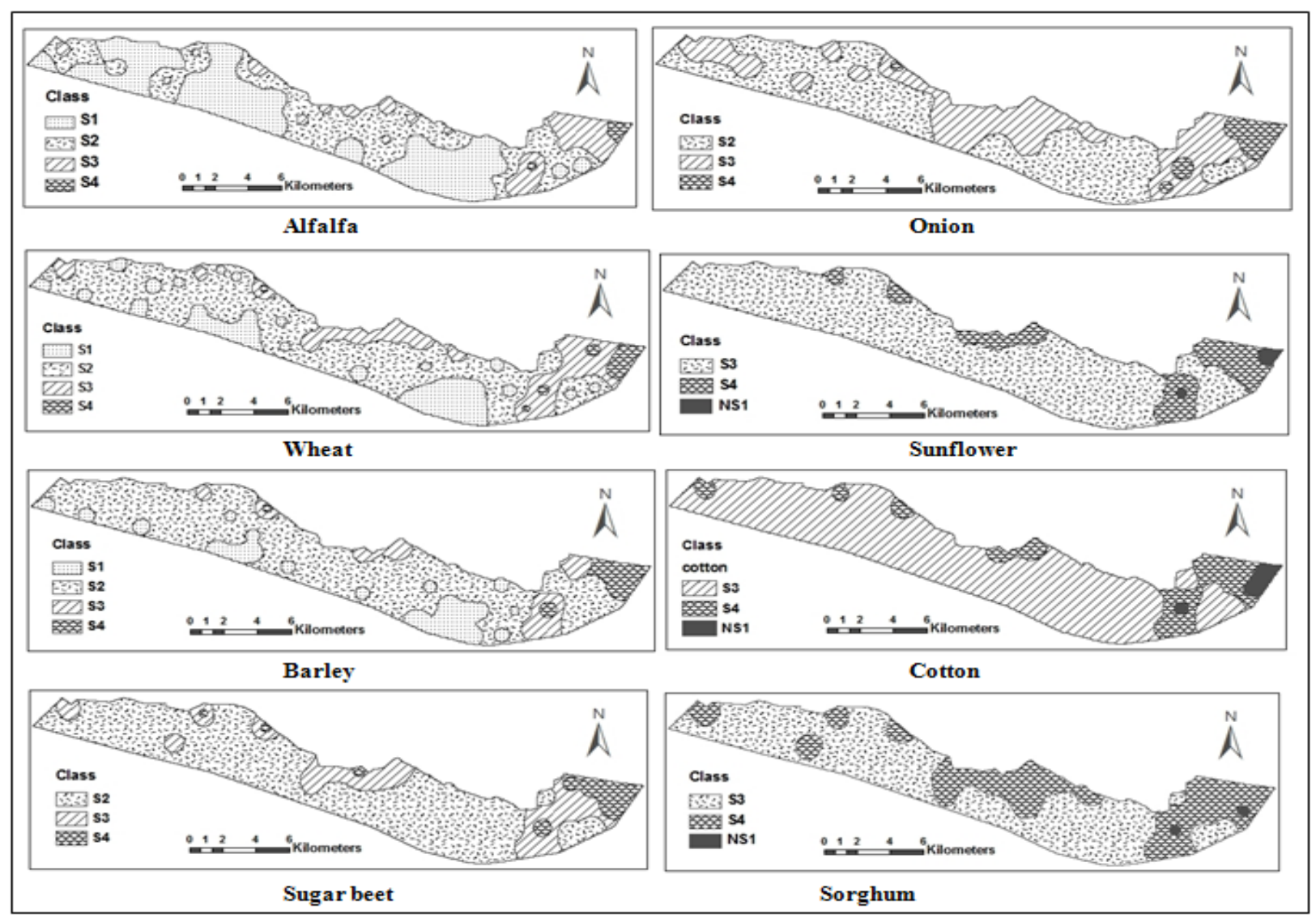

Fig. 6. Spatial distribution of land suitability classes for some field crops in the Southeastern sector of Siwa oasis 
The area percent of S3 class for fruit crops is in the following order: date palm $>$ fig $>$ olive $>$ grape $>$ pear with area percent $87,74,67,58$ and $37 \%$, respectively (Table 4). However, the descending order for class S4 is grape $>$ olive $>$ fig $>$ pear $>$ date palm with area percent $38,27,20,9$ and 7, respectively. Very small areas (2 - 4 $\%)$ are classified as NS1 and NS2 (actually unsuitable) for these fruit crops (Table 4). The low suitability classes mostly occur in the Eastern and the Northern parts of the study area (Fig. 6 and 7). This may be explained by their high $\mathrm{CaCO}_{3}$ contents, high $\mathrm{EC}$ and/or ESP \% values, and shallow soil depth (Fig. 4).

The dominant limiting parameter for crop suitability of most crops is the coarse soil texture (Table 1). The secondary limiting parameters affecting the suitability of field, fodder, and vegetables crops are high levels of soil salinity and alkalinity and high soil permeability. Calcium carbonate content is the main limiting parameter for citrus cultivation while shallow soil depth is a considerable limiting parameter for most fruits trees.

\section{CONCLUSIONS}

The descriptive statistical analysis of soil properties showed that soil salinity, soil alkalinity, organic matter content, available nutrients ( $\mathrm{N}, \mathrm{P}$, and $\mathrm{K}$ ) and soil depth represent high variability and this reflects the high variation among soil units. Seven soil subunits are represented in the study area, the most dominant three subunits are calcareous-alkaline-saline to very salinevery deep, calcareous-alkaline-extremely saline-very deep, and calcareous-non-alkaline-saline to very salinevery deep. These subunits represent area percent of $32 \%, 30 \%$, and $28 \%$ of the total area, respectively.

The use of ALESarid-GIS as an integrated GISbased land evaluation model facilitates the identification of the best agricultural land use within the study area. The most suitable crops to grow in the study area are alfalfa, wheat, barley, sugar beet, onion, pear, date palm, sunflower, cotton, fig, olive, sorghum, and grape in the order indicated. The general dominant limiting parameters affecting crop suitability are coarse soil texture, soil salinity, soil permeability, exchangeable sodium percent (ESP). Calcium carbonate content is the main limiting parameter for citrus cultivation and shallow soil depth is a considerable limiting parameter for most of the fruits trees.

The outcomes of this research present a valuable guide for decision-makers and farmers to make their choices for best agricultural management and prevent land desertification in future land reclamation projects in Siwa oasis.

\section{AKNOWLODGEMENT}

The field work of this research was supported by the research project "Sustainable Development of Fragile Agroecosystems: A case study of Siwa oasis", financed by the Agricultural Research and Development Fund, ARDF (2010-2014).

\section{REFERENCES}

Abd Elkawy, O.R., H.A. Ismail., J.K. Rød., and A.S. Suliman. 2010. A Developed GIS-based Land Evaluation Model for Agricultural Land Suitability Assessments in Arid and Semi-Arid Regions. Research Journal of Agricultural and Biological Sciences, 6 (5); 589-599.

Abd Elkawy, O.R., J.K. Rød., H.A. Ismail and A.S. Suliman. 2011. Land Use and Land Cover Change Detection in the Western Nile Delta of Egypt Using Remote Sensing Data. Applied Geography, 31; 483-494.

Adriansen, H.K. 2009. Land reclamation in Egypt: A study of life in the new lands. Geoforum 40 (4), 664-674.

Aronoff, S. 1989. GIS a Management Perspective. WDL Publications, Ottawa, Canada.

Ayers, R.S., and D.W. Westcott. 1985. Water quality for agriculture. FAO Irrigation and Drainage Paper No. 29 (Rev. 1). Rome.

Bush, R. 2007. Politics, power and poverty: Twenty years of agricultural reform and market liberalization in Egypt. Third World Quarterly 28 (8), 1599-1615.

CAPMS. 2016. The Central Agency for Public Mobilization and Statistics. The Arab Republic of Egypt. http://www.capmas.gov.eg/ (last access: 14/08/2016).

Carver, S.J. 1991. Integrating multi-criteria evaluation with geographical information systems. Int. J. Geographic Information Systems. 5 (3), 321-339.

Corbett, J.D. 1996. Dynamic crop environment classification using interpolated climate surfaces. In: Goodchild, M.F., Steyaert, L.T., Parks, B.O. (Eds.), GIS and Environmental Modeling: Progress Research Issues. GIS World Book, Fort Collins, pp. 117-122.

ESRI. 2015. Environmental Systems Research Institute. What's new in ArcGIS 10.3.1 for Desktop. http://desktop.arcgis.com/en/arcmap/10.3/main/getstarted/whats-new-in-arcgis-1031.htm

FAO. 1970. Food and Agriculture Organization. Physical and chemical methods of soil and water analysis. Soils Bulletin No.10, FAO, Rome.

FAO. 1976. Food and Agriculture Organization. A framework for land evaluation. Soils Bulletin 26. Food and Agriculture Organization of the United Nations (FAO), Rome, Italy.

FAO. 1990. Guidelines for soil profile description. 3rd ed., FAO, Rome.

FAO. 2005. Food and Agriculture Organization. Fertilizer Use by Crop in Egypt. First version. Food and Agriculture Organization of the United Nations (FAO), Rome. 
IFAD. 2005. International Fund for Agricultural Development. Document of the International Fund for Agricultural Development. The Arab Republic of Egypt Country Programme Evaluation. Report No. 1658-EG.

Jackson, M.L. 1973. Soil chemical analysis. Advanced course Ed.2. A Manual of methods useful for instruction and research in soil chemistry, physical chemistry of soil, soil fertility and soil genesis. Revised from Original Edition (1955)

Jankowski, P., N. Andrienko, and G. Andrienko. 2001. Mapcentered exploratory approach to multiple criteria spatial decision making. Int. J. Geog. Inf. Sys. 15 (2), 101-127.

Lee, G. 2003. "A GIS-based Model for Evaluating Agricultural Land based on Crop Equivalent Rate (CER)", In Proceeding of $23^{\text {rd }}$ Annual ESRI International User Conference, San Diego, CA.

Malczewski, J. 2004. GIS-based land-use suitability analysis: a critical overview. Progress in Planning . 62, 3-65.

MALR. 2001. Report on desert reclamation in Egypt: Five years plan (pp. 55-59, in Arabic). Ministry of Agriculture and Land Reclamation (MALR), Dokki, Cairo, Egypt.

Olsen, S.R., and F.S. Watanabe. 1965. Test of an Ascorbic Acid Methods for Determining Phosphorus in water and $\mathrm{NaHCO}_{3}$ Extracts from Soil. Soil Sci. Soc. Proc., 29: $677-$ 678.
Page, A.L.; R.H. Miller, and R. Keeny. 1982. "Methods of soil analysis. Part 2. Chemical and microbiological properties. Agron. Monograph No. 9, ASA, Madison, WI, USA.

Pereira, J.M., and L. Duckstein. 1993. A multiple criteria decision-making approach to GIS-based land suitability analysis. Int. J. Geog. Inf. Sys. 7:407-24.

Richards, R.L. (ed.) 1954. Diagnosis and improvement of saline and alkaline soils. Agriculture Handbook No. 60, U.S Govern. Printing Office, Washington, USA.

Rossiter, D.G. 1996. A theoretical framework for land evaluation. Geoderma .72, 165-190.

Rossiter, D.G. 2003. Biophysical models in land evaluation. In: Encyclopedia of Life Support Systems (EOLSS), Theme 1.5 Land Use and Land Cover (ed W.H. Verheye), Oxford: EOLSS publishers developed under the auspices of UNESCO. Article 1.5.27. pp: 1-16.

SIS. 2016. State Information Services (SIS). The Mega National Project: A Locomotive of Development, The National Project for Reclamation and Cultivation of one million and a half http://www.sis.gov.eg/section/352/4683?lang=en-us (last accessed 24 August 2016).

USDA. 2010. United States Department of Agriculture. Keys to Soil Taxonomy. Eleventh Edition. Washington, D.C.

USGS. 2016. United States Geological Survey. Earth explorer. http://earthexplorer.usgs.gov/ (last accessed 16 March 2016). 


\section{الملخص العربي \\ تقويم ملائمة الأرض للزراعة في القطاع الجنوبى الثرقي لواحة سيوة}

$$
\text { رمزي مرسي رزق هدية، أسامة راضي عبد القوي }
$$

وكذلك درجة صودية التربة. وقد أوضحت نتــائج تحليـلـل

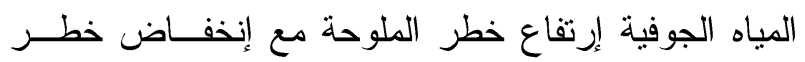
تدهور الصودية في التربة عند استخدام هذه المياه في الري

.(C3S1 class)

وقد دلت نتائج تحليل درجة ملائمسـة اســتخدام الأرض للزر اعة Land use suitability classes باســتخدام برنـــامج ALESarid-GIS عالية إلى منوسطة High to Moderate الملائمة (S1 to S2) لزر اعة محاصيل البرسيم الحجازي و القمح و الثعير وبنجر

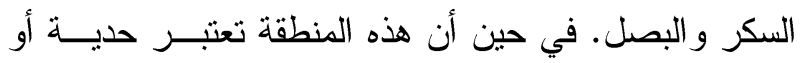
مشروطة Marginal to Conditional الملائمــة (S3 to S4) لزر اعة محاصيل الكمثزى ونخيل الــبلح وعبــاد الثــمس



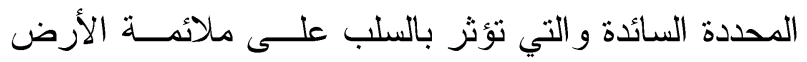
لزر اعة المحاصيل المختلفة هي قو ام التربة الخشن وملوحة

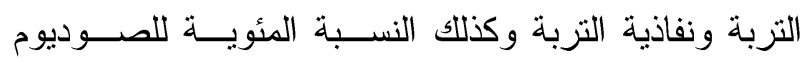
المتبادل. وتعتبر مخرجات هذه الدراســة البحثيــة بمثابـــة مصدر ذو قيمة تطبيقية للهيئات الحكومية المهتمة بمشاريع استصلاح الأراضي و التي تأخذ أيضا في اعتبارها التتميــة الزر اعية المستدامة في واحة سيوة.
في ضوء الزيادة السكانية المستمرة وتتامي الازدحام في نطاق وادي ودلتا النيل، بات من الضروري بمكان الحاجة إلى استصلاح المزيد من مساحات الأراضي الصـــر اوية في مصر • وقد حاولت هذه الدراسة بحث أفضل اســتخدام للأر اضي في الزر اعة لإضافة مساحة زر اعية جديدة فــي القطاع الجنوبى الثرقي من واحة سيوة، وذللك إستتادا إلـى لـى

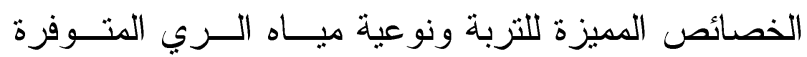
بمنطقة الدر اسة. وقد أجريت الدراسة الحقلية خلال عام سا ــ حيث تم تجميع العينات الممثلة للتزبة و المياه الجوفية المتاحة والتـي سوف تستخدم في الري لإجر اء التحاليـلـل اللازمـــة لهــــا

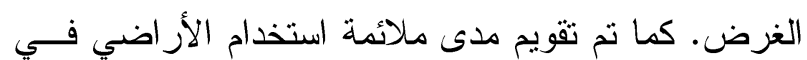

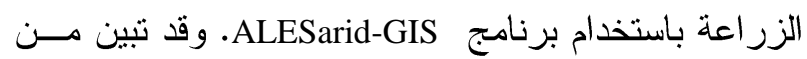

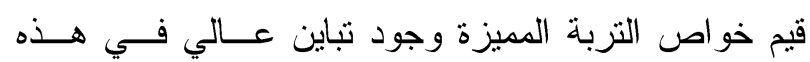


التربة المشبعة من ror, • إلى ^ • r د. ســيمنز/م، ونســبة

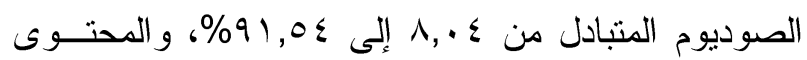

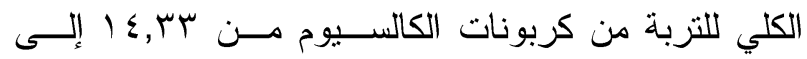

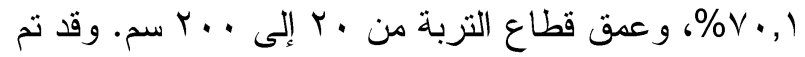
تمثيل أنو اع الترب في منطقة الدراسة بسبع وحدات أرضية فرعية بناء على خصاص عمق القطاع وملوحــة التربــة 